\title{
Prevalence of functional disability in the elderly: analysis of the National Health Survey
}

\author{
Prevalência de incapacidade funcional em idosos: análise da Pesquisa Nacional de Saúde
}

Danielle Samara Tavares de Oliveira-Figueiredo ${ }^{1}$, Mariana Santos Felisbino-Mendes ${ }^{2}$, Deborah Carvalho Malta ${ }^{2}$, Gustavo Velasquez-Melendez ${ }^{2}$

Objective: to verify the prevalence of functional disability to perform basic and instrumental activities of daily living in the elderly. Methods: this is a cross-sectional study using data from the National Health Survey, whose sample was 7,373 elderly. Results: the prevalence of functional incapacity for basic and instrumental activities was 8.4\% (Confidence Interval 95.0\%: 7.4-9.4) and 22.0\% (Confidence Interval 95.0\%: $20,4-23.6$ ), respectively, being higher in females, in those older ( $>75$ ) and without levels of education. Demographic aspects, such as lower age and male sex, attenuated the prevalence of disability. Conclusion: the elderly showed a higher prevalence of functional disability for instrumental activities such as shopping, administering finances, taking medicines and going out on their own.

Descriptors: Frail Elderly; Activities of Daily Living; Prevalence; Health Surveys.

Objetivo: verificar a prevalência de incapacidade funcional para realização de atividades básicas e instrumentais de vida diária em idosos. Métodos: estudo transversal que utilizou dados da Pesquisa Nacional de Saúde, cuja amostra foi de 7.373 idosos. Resultados: a prevalência de incapacidade funcional para atividades básicas e instrumentais foi de 8,4\% (Intervalo de Confiança 95,0\%: 7,4-9,4) e 22,0\% (Intervalo de Confiança 95,0\%: 20,4$23,6)$, respectivamente, sendo maior no sexo feminino, naqueles mais longevos (>75) e sem níveis de instrução. Aspectos demográficos, como menor faixa etária e sexo masculino, atenuaram a prevalência de incapacidade. Conclusão: os idosos apresentaram maior prevalência de incapacidade funcional para as atividades instrumentais tais como, fazer compras, administrar finanças, tomar remédios e sair sozinho.

Descritores: Idoso Fragilizado; Atividades Cotidianas; Prevalência; Inquéritos Epidemiológicos.

${ }^{1}$ Universidade Federal de Campina Grande. Cuité, PB, Brazil.

${ }^{2}$ Universidade Federal de Minas Gerais. Belo Horizonte, MG, Brazil.

Corresponding author: Danielle Samara Tavares de Oliveira-Figueiredo

Universidade Federal de Campina Grande, Centro de Educação e Saúde. Sítio Olho d’Água da Bica, s/n, Centro. CEP: 58175-000. Cuité, PB, Brazil. E-mail: daniellesamara@hotmail.com 


\section{Introduction}

The global increase in life expectancy when associated with declining fertility and mortality rates results in a pronounced aging population. It is noticed that the speed of this change in the age structure does not occur homogeneously among the countries, being more recent and intense in those of low and middle income, such as Brazil ${ }^{(1)}$. With the proportional increase of the elderly, the needs of health actions and services become more complex, as there is a tendency for organic functions to decline as a function of age, as well as an increased risk of chronic diseases, which can also promote functional problems.

Functional capacity or functionality refers to the maintenance of physical and mental abilities to perform the daily activities necessary for an independent and autonomous life, reflecting well-being and quality of life, considered as an important indicator of geriatric health ${ }^{(1)}$. However, functional disability is a strong predictor of mortality in the elderly ${ }^{(2)}$.

The Northeast Region of Brazil has a shortage of population-based surveys evaluating the functionality of the elderly. Previous studies that measured the prevalence of this phenomenon in the region show little capacity for generalization of the findings due to the use of local samples, constituting a lacuna, due to the lack of representativeness for the states as a who$\mathrm{le}^{(3-4)}$. Previous national investigations were focused on the evaluation of the Southeast and South regions of the country ${ }^{(5)}$.

Also, there are different techniques for measuring functionality, for example, through clinical aspects, scales, and motor performance tests. In epidemiological surveys, this measurement is often performed by self-report of the difficulty or the need for help to perform basic and instrumental activities of daily living.

This reality hinders to compare the prevalence of functional disability between different contexts and genders and may explain, in part, the large variation in the proportions of this outcome among Brazilian elderly, with values ranging from 12.3 to $94.1 \%$ for men and 14.9 to $84.6 \%$ for women ${ }^{(5)}$. Some studies indicate higher rates in women ${ }^{(2-3)}$. Also, these differences in the prevalence of functional disability in the elderly are also related to the demographic, socioeconomic determinants, health conditions, lifestyles, and the characteristics of the physical and social environment $t^{(6,3-4)}$.

The results of this research will provide an overview of the situation of the functionality in the elderly of the region, considering the need for surveys that use the same form of measurement for this outcome and a representative sample of the elderly living in the Northeast. The objective of this study was to verify the prevalence of functional disability to perform basic and instrumental activities of daily living in the elderly.

\section{Methods}

This is a cross-sectional study that used data from the National Health Survey conducted in 2013. The National Health Survey consists of a home-based epidemiological survey aimed, in a general way, to produce data of national representativity to characterize the situation of health and lifestyles of the Brazilian population, as well as, subsidize means to evaluate health care. The process of complex sampling by clusters occurred in three stages: the census tracts formed the Primary Sampling Units; the households were constituted in units of the second stage; and residents of 18 years old or older composed the third stage units ${ }^{(7)}$.

An adult resident was selected by simple random sampling, in each household, to investigate specific health topics. In households with elderly residents, they responded to the specific health module of the elderly. Also, when the elderly were not present or could not respond, the questionnaire was answered by the head of the household, or the proxy ${ }^{(7)}$.

Data collection was performed using handheld micro-computers by interviewers who received technical and theoretical training. In this study, the data on 
the health of the elderly (module $\mathrm{K}$ ), general characteristics of the residents (module $\mathrm{C}$ ) and educational characteristics of the person five years old or more (module D) were analyzed.

Individuals with 60 years old or more residing in the Northeast region were selected, totaling 7,323, excluding those who participated in the National Health Survey and resided in other regions. More information on the data collection, questionnaire and sample plan are available at the electronic address of the Brazilian Institute of Geography and Statistics and the published volumes of the research ${ }^{(7)}$.

Functional disability was defined as the difficulty or impossibility of performing activities in various domains of life, including basic and instrumental actions of daily living ${ }^{(6)}$. For their evaluation, the interviewees were asked about the difficulty in performing six basic activities (feeding, bathing, dressing, going to the bathroom, walking from one room to another and lying down and getting out of bed alone) and four activities (shopping, administering finances, taking medicines and going out on their own).

The elderly were considered as a functional incapacity for basic activities when they answered the options: 1) I cannot or 2) I have great difficulty, in at least one of the six basic activities. Likewise, they were considered incapable of instrumental actions when they answered the options: 1) I cannot or 2) I have great difficulty in at least one of the four instrumental activities questioned. Those who answered the options: 3) I have little difficulty and 4) I have no difficulty, were considered without functional problems. The assessment of functional problems through daily activities is recommended by theoretical models and frequently used in epidemiological surveys because they are survival actions ${ }^{(3,6)}$.

Stata ${ }^{\circledR}$ software version 14 and the functions of the survey module for complex samples were used for data analysis. The prevalence and Confidence Interval (CI) $95.0 \%$ of confidence $(95.0 \% \mathrm{CI})$ for functio- nal disability in basic and instrumental activities were stratified according to the following variables: a) gender (male; female); B) age group (in years: 60 to 64, 65 to 74,> 75); C) Education level (without education, incomplete elementary school, complete primary education or more); and d) race/color of the skin (white, black, brown). All analyses were performed using the sample weights.

The study complied with the formal requirements contained in the national and international regulatory standards for research involving human beings.

\section{Results}

It was observed a predominance of female elderly (55.7\%), aged 65-74 years old (43.2\%), brown skin color (41.1\%) and low educational level $(85.1 \%$ of the elderly had complete or incomplete primary education and no education). The prevalence of functional disability was 8.4\% (CI95.0\%: 7.4-9.4) for basic activities and 22.0\% (CI95.0\%: 20.4-23.6) for Instrumental activities.

Table 1 describes the prevalence of functional disability stratified by gender, age group, education level and race/ skin color.

It is possible to observe a higher prevalence of functional problems in females, in those who are longer-lived and without formal education levels. The elderly without education levels had a higher prevalence of disability in basic activities (10.5\%; 95.0\% CI: 9.0-12.0) and also in instrumental activities (28.0\%; CI 95.0\%: 25.6-30.4). The lower proportions of limitations were observed in the elderly with higher education (complete elementary school or more). Regarding race-color, the elderly who declared to be black showed a higher proportion of incapacity for basic activities (9.8\%, 95.0\% CI: 6.7-12.8), while for the performance of the instruments, the white-race had a higher proportion (23.2\%, 95.0\% CI: 20.4-26.1). 
Table 1 - Prevalence (\%) of functional incapacity to perform basic and instrumental activities of daily living in the elderly $(n=7,337)$

\begin{tabular}{|c|c|c|}
\hline Variable & $\begin{array}{l}\text { Inability for basic } \\
\text { activities of daily } \\
\text { living }\end{array}$ & $\begin{array}{l}\text { Inability to perform } \\
\text { instrumental activi- } \\
\text { ties of daily living }\end{array}$ \\
\hline & $\%(\mathrm{CI} 95 \%)^{*}$ & $\%(\mathrm{CI} 95 \%)$ \\
\hline \multicolumn{3}{|l|}{ Gender } \\
\hline Male & $7.3(5.7-8.8)$ & $17.2(15.3-19.2)$ \\
\hline Female & $9.3(7.8-10.8)$ & 25.8 (23.7- 27.8) \\
\hline \multicolumn{3}{|l|}{ Age group (in years) } \\
\hline $60-64$ & $3.1(2.1-4.0)$ & $7.7(6.2-9.2)$ \\
\hline $65-74$ & $5.4(4.4-6.3)$ & $14.8(12.9-16.6)$ \\
\hline$>75$ & $18.9(15.7-22.1)$ & $49(45.6-52.3)$ \\
\hline \multicolumn{3}{|l|}{ Education level } \\
\hline Without education & $10.5(9.0-12.0)$ & $28.0(25.6-30.4)$ \\
\hline Incomplete Elementary school & $6.5(5.3-7.7)$ & $19.3(17.1-21.6)$ \\
\hline $\begin{array}{l}\text { Complete Elementary schoool } \\
\text { or more }\end{array}$ & $5.6(3.1-8.0)$ & $10.1(7.4-12.8)$ \\
\hline \multicolumn{3}{|l|}{ Race/skin color } \\
\hline White & $9.6(7.8-11.3)$ & $23.2(20.4-26.1)$ \\
\hline Black & $9.8(6.7-12.8)$ & $22.2(17.5-27.0)$ \\
\hline Brown & $7.6(6.1-9.1)$ & $21.4(19.2-23.6)$ \\
\hline
\end{tabular}

The Northeastern state in which the elderly presented the worst functional condition for basic activities were: Alagoas (10.3\%, CI95.0\%: 7.7-12.9); Paraíba (10.2\%, 95.0\% CI: 7.5-13.0) and Pernambuco (9.7\%, CI 95.0\%: 6.9-12.2). The lowest proportion of disability was found in Ceará (6.5\%; 95.0\% CI: 4.78.3), all within the confidence interval, with no statistically significant differences.

Regarding the instrumental activities, elderly people in Paraíba and Rio Grande do Norte presented the highest prevalence of this outcome $(26.0 \% ; 95.0 \%$ CI: 21.4-30.5 and 26.0\%; 95.0\% CI: 22.1-29.9 respectively). The lowest proportion was found among Sergipe (18.0\%; 95.0\% CI: 14.5-21.6). In all Northeastern states, there was a trend towards a higher prevalence of functional disability in females for both daily activities, except in Piauí, where functional problems for basic actions were more prevalent in males $(7.0 \%$; CI 95.0 \%: 4.2-9.8) (Table 2).
Table 2 - Prevalence (\%) of functional disability for basic and instrumental activities of daily living in the elderly ( $\geq 60$ years old) $n=7,337$

\begin{tabular}{|c|c|c|c|}
\hline \multirow[b]{2}{*}{$\begin{array}{l}\text { Functional } \\
\text { ties/Region }\end{array}$} & \multicolumn{2}{|c|}{ Gender } & \multirow[b]{2}{*}{$\begin{array}{c}\text { Total \% } \\
\text { (CI95\%) }\end{array}$} \\
\hline & $\begin{array}{c}\text { Male } \\
\%(\mathrm{CI} 95 \%)^{*}\end{array}$ & $\begin{array}{c}\text { Female } \\
\%(\mathrm{CI} 95 \%)\end{array}$ & \\
\hline \multicolumn{4}{|c|}{ Basic activities of daily living } \\
\hline Maranhão & $8.8(5.9-11.6)$ & $8.5(4.8-12.2)$ & $9.0(4.6-13.5)$ \\
\hline Piauí & $6.9(4.3-9.4)$ & $7.0(4.2-9.8)$ & $6.8(3.5-10.1)$ \\
\hline Ceará & $6.5(4.7-8.3)$ & $5.9(3.0-8.8)$ & $7.0(4.5-9.4)$ \\
\hline Rio Grande do Norte & $9.6(6.9-12.2)$ & $7.7(4.0-11.5)$ & $11.1(7.5-14.7)$ \\
\hline Paraíba & $10.2(7.5-13.0)$ & $9.3(5.4-13.2)$ & $10.9(7.1-14.7)$ \\
\hline Pernambuco & $9.7(7.5-11.8)$ & $8.0(5.2-10.9)$ & $10.9(7.8-14.1)$ \\
\hline Alagoas & $10.3(7.7-12.9)$ & $8.1(4.4-11.8)$ & $12.0(8.2-15.8)$ \\
\hline Sergipe & $7.7(5.6-9.8)$ & $5.8(3.0-8.70$ & $9.2(5.9-12.5)$ \\
\hline Bahia & $7.9(5.0-10.9)$ & $6.6(1.7-11.5)$ & $8.9(4.6-13.2)$ \\
\hline Nordeste & $8.4(7.4-9.4)$ & $7.3(5.7-8.8)$ & $9.3(7.8-10.8)$ \\
\hline \multicolumn{4}{|c|}{ Instrumental activities of daily living } \\
\hline Maranhão & $25.7(20.6-30.8)$ & $25.1(17.7-32.5)$ & $26.3(19.1-33.5)$ \\
\hline Piauí & $19.5(15.6-23.4)$ & $16.5(11.9-21.0)$ & $22.4(17.7-27.0)$ \\
\hline Ceará & $20.3(17.2-23.4)$ & $15.1(11.4-18.8)$ & $24.5(20.3-28.7)$ \\
\hline Rio Grande do Norte & $26.0(22.1-29.9)$ & $19.0(14.0-24.1)$ & $31.8(26.5-37.1)$ \\
\hline Paraíba & $26.0(21.4-30.5)$ & $21.2(15.4-27.0)$ & $29.5(24.5-34.5)$ \\
\hline Pernambuco & $19.9(17.2-22.7)$ & $12.9(9.6-16.2)$ & $25.4(21.5-29.4)$ \\
\hline Alagoas & $24.6(20.8-28.3)$ & $17.4(12.2-22.6)$ & $30.4(25.6-35.1)$ \\
\hline Sergipe & $18.0(14.5-21.6)$ & $13.0(9.0-17.0)$ & $21.9(16.9-26.9)$ \\
\hline Bahia & $21.6(17.2-26.1)$ & $17.6(12.0-23.2)$ & $24.5(18.7-30.2)$ \\
\hline Nordeste & $22.0(20.4-23.6)$ & $17.2(15.3-19.2)$ & $25.8(23.7-27.8)$ \\
\hline
\end{tabular}

\section{Discussão}

This research used a self-reported measure of functional disability. This type of assessment can affect the accurate estimates of the prevalence of this outcome. However, other forms of measurement, such as motor performance tests, present difficulties in applying large populations. It is also considered the limitation inherent in the cross-sectional design because it is obtained only once and without temporal follow-up, but it is important for generating hypotheses. 
It was observed in this investigation that the prevalence of functional problems for instrumental activities was 2.6 times higher than for basic activities, maintaining this pattern of difference for all Northeast states. The older females, of the older age group and without education levels, presented higher proportions of functional disability. Similar results were found ${ }^{(3,5,8)}$ and indicate that social and gender aspects may have implications for the prevalence of functional disability in the elderly.

One factor among the biopsychosocial aspects that could explain the higher prevalence of female disability in most Northeastern states is the fact that women have a higher life expectancy than $\operatorname{men}^{(9)}$. Thus, the lower longevity in males leads to a lower probability of survival with a disability, aspects that can only be observed in prospective cohorts.

International research agrees with this pattern of difference between genders. The World Health Survey, conducted in low and middle-income countries, estimated that functional problems were also higher in women in all 43 countries studied, with the exception of the Czech Republic ${ }^{(10)}$. In the context of lower socioeconomic inequality, as in the case of the United States, it was found that although women lived longer, in the older age groups, they are less functionally active than men ${ }^{(11)}$.

Another possible explanation is that females are more prone to the fragility syndrome, a more vulnerable condition to diseases, and can be investigated by the loss of reserves, such as energy, functional capacity, cognition and health ${ }^{(12)}$. On the other hand, nutritional status seems to influence functional capacity. Elderly people living in the community and suffering from loss of muscle mass and central obesity have worse functional performance in basic and instrumental activities. Also, female and older individuals are independent risk factors associated with a decline in instrumental activities ${ }^{(13)}$.

Functional decline, with increasing age, was also evidenced in the international context ${ }^{(10)}$, in which elderly people reported having functional proble- ms more frequently, in relation to the younger ones. These results confirm a positive relationship between declining functionality and increasing age.

Also, the inverse relationship between functional incapacity and education, in countries with socioeconomic levels similar to the context studied, was also verified $^{(11)}$. Socioeconomic conditions stratify population groups according to education, income levels, gender, housing region, among others. The differences in access to education levels according to family income and skin color in Brazil, especially the black population, northeasterners and the rural population ${ }^{(14)}$.

A study that used data from the National Household Sample Survey between 1995 and 2009 showed high percentages of poor individuals who were not able to complete elementary or high school. Those with high income had greater access to higher education, $60.0 \%$, a percentage that is similar to developed countries. There are also differences in access between white and non-white people, however, the effect of income on access to education is greater than the skin color $^{(15)}$.

Perhaps the effect of lower access to education among black people in Brazil explains, in part, the higher prevalence of functional disability for basic activities in the elderly who declared to be black. Low education level has repercussions on the type of work that people perform, with people with low instructional levels normally destined for "heavy/manual" services, which can lead to impaired functional capacity.

It was also verified that the elderly in the Northeast presented a high prevalence of functional disability since the proportions in this region are superior to those observed nationally ${ }^{(7)}$. Another research on disability assessment with National Health Survey data showed that the national prevalence of functional impairment among the elderly was 6.8\% (CI95.0\%: 6.3-7.3) and 17.3\% (IC95.0\%: 16.5-18.2) for basic and instrumental activities, respectively, being higher among elderly people living in rural areas ${ }^{(7)}$. Similar results were observed in systematic reviews ${ }^{(5)}$ and in investigations with smaller populations ${ }^{(3,8)}$. 
Also, it was observed that the specific proportion of limitation for basic activities was also higher in the elderly in the Northeast than in other regions. The North region has the lowest proportion of elderly people with limitations to basic activities with $5.7 \%\left({ }^{(7)}\right.$. Regarding the difficulties in performing instrumental activities, the Northeast region also obtained the highest prevalence in Brazil. The lowest proportions were observed in the elderly in the South $(15.3 \%$, 95.0\% CI: 13.4-17.1) and Southeast (15.5\%, CI 95.0\%: $14.1-16.9)^{(7)}$.

Other similar investigations estimated proportions of incapacity for basic and instrumental activities of elderly people superior to the results of this research. However, they were limited to use samples that do not have regional representativeness, which makes their comparability difficult. A study carried out with 316 elderly people found that the prevalence of dependence for instrumental actions was $41.0 \%$ and $16.0 \%$ for basic activities ${ }^{(3.8)}$.

These differences in regional estimates of the prevalence of functional disability could be partially explained by their individual and environmental determinants. From the point of view of the social environment, Brazil presents high levels of socioeconomic inequalities ${ }^{(9)}$, evidenced by differentiated circumstances in the broad sense, in which people are born, grow, work and grow old, generating different functional capacity outcomes.

Also, in the Brazilian states with lower life expectancies, three are from the Northeast: Alagoas (70.8 years old); Piauí (70.7 years old) and Maranhão (70 years old) ${ }^{(16)}$. The Region's illiteracy rate is the highest in the country, reaching 18.9 in 2013, almost double the national rate for the same year, which was 8.5. In Brazil, illiteracy is more frequent among the elderly, with the national rate in 2013 reaching 27.7 in people aged 65 and over ${ }^{(17)}$. Another aspect that could justify the regional variations in the proportion of functional incapacity is the smaller access to the health services. There are inequalities in coverage and provision of care between regions and municipalities with important repercussions on the health of populations $^{(18)}$.

This research also verified that in the northeastern states, Alagoas obtained higher prevalence of functional disability for basic activities in the elderly. The State is marked by high social inequality and worse health indicators of the country, thus, the high prevalence of disability may have some relation to the coverage of the family health strategy and other social indicators $^{(18)}$.

The states of Paraíba and Rio Grande do Norte presented the highest prevalence of incapacity for instrumental activities among the elderly in the Northeast. The high prevalence of functional disability in this study was contrasted with data on health service coverage. According to data from the National Health Survey in 2013, Paraíba ranks second among Federative Units, with a higher number of households enrolled in Family Health Units (78.6\%).

On the other hand, Rio Grande do Norte is the third state in the region with the lowest proportion of households registered (63.4\%), with only Bahia (58.5\%) and Pernambuco (63.3\%) ahead. This could explain, in part, the high prevalence of disability in that state ${ }^{(19)}$. However, the registration of domicile and residence does not necessarily reflect the offer and adequate quality of care.

These results can contribute to the knowledge of the functionality of the elderly, offering subsidies to managers, researchers, and health professionals, with a view to directing integrated, transversal and cross-sectoral policies and actions towards healthy aging.

\section{Conclusion}

The elderly in the Brazilian Northeast had a higher prevalence of functional incapacity to perform instrumental activities, such as shopping, administering finances, taking medicines and going out alone. There are important factors that may explain the ine- 
quities in the proportions of functional disability, with emphasis on education levels, since the prevalence of this outcome in the elderly with high education in the Northeast reaches proportions comparable to those in more developed regions. Demographic factors, such as the lower age range and the male sex, attenuated the prevalence of disabilities.

\section{Collaborations}

Oliveira-Figueiredo DST, Felisbino-Mendes MS, and Velasquez-Melendez G contributed in the writing of the article, analysis and interpretation of data and critical review of the intellectual content. Malta DC contributed to designing and project, relevant critical review of intellectual content. All authors contributed to the final approval of the version to be published.

\section{References}

1. World Health Organization. World report on Ageing and Health [Internet]. 2015 [cited 2017 Jun 19]. Available from: http://apps.who.int/iris/bitstream/10665/186463/1/9789240694811_eng. pdf

2. Confortin SC, Schneider IJC, Antes DL, Cembranel F, Ono LM, Marques LP, et al. Life and health conditions among elderly: results of the EpiFloripa Idoso cohort study. Epidemiol Serv Saude. 2017; 26(2):1-12. doi: http://dx.doi.org/10.5123/ s1679-49742017000200008

3. Freitas RS, Fernandes MH, Coqueiro RS, Reis Júnior W, Rocha SV, Brito TH. Functional capacity and associated factors in the elderly: a population study. Acta Paul Enferm. 2012; 25(6):9339.doi:http://dx.doi.org/10.1590/S010321002012000600017

4. Almeida TZS, Santos CA, Rocha SV, Pedreira RBS, Pinto-Junior EP. Prevalence of functional disability and associated factors among elderly in rural areas. Rev Cienc Med Biol [Internet]. 2016 [cited 2017 Jun 19]; 15(2):199-203. Available from: https://portalseer.ufba.br/index.php/cmbio/ article/view/16996/12745
5. Campos ACV, Almeida MHM, Campos GV, Bogutch TF. Prevalence of functional incapacity by gender in elderly people in Brazil: a systematic review with meta-analysis. Rev Bras Geriatr Gerontol. 2016; 19(3):545-59. doi: http://dx.doi. org/10.1590/1809-98232016019.150086

6. Duarte MCS, Loureiro LSN, Fernandes MGM, Nóbrega MML, Costa KNFM. Functional disability in the elderly's conceptual analysis. Rev Enferm UFPE on line [Internet]. 2012 [cited 2017 Jun 19]; 6(10):2348-55. Available from: http://www. revista.ufpe.br/revistaenfermagem/index.php/ revista/article/viewArticle/2718

7. Instituto Brasileiro de Geografia e Estatística. Pesquisa Nacional de Saúde, 2013. Ciclos de vida [Internet]. 2015 [citado 2017 jun. 19]. Disponível em:http://biblioteca.ibge.gov.br/visualizacao/ livros/liv94522.pdf

8. Nunes JD, Saes MO, Nunes BP, Siqueira FCV, Soares DC, Fassa MEG. Functional disability indicators and associated factors in the elderly: a population-based study in Bagé, Rio Grande do Sul, Brazil. Epidemiol Serv Saúde. 2017; 26(2):295-304. doi: http://dx.doi.org/10.5123/ S1679-49742017000200007

9. Instituto Brasileiro de Geografia e Estatística. Síntese de indicadores sociais: uma análise das condições de vida da população brasileira. Rio de Janeiro: Instituto Brasileiro de Geografia e Estatística; 2014.

10. Hosseinpoor AR, Bergen N, Kostanjsek N, Kowal P, Officer A, Chatterji S. Socio-demographic patterns of disability among older adult populations of low-income and middle-income countries: results from World Health Survey. Int J Public Health. 2016; 61(3):337-45. doi: http://dx.doi. org/10.1007/s00038-015-0742-3

11. Freedman VA, Wolf DA, Spillman CB. Disabilityfree life expectancy over 30 years: a growing female disadvantage in the us population. Am J Public Health. 2016; 106(6):1079-85. doi: http:// dx.doi.org/10.2105/AJPH.2016.303089

12. Fhon JRS, Diniz MA, Leonardo KC, Kusumota L, Haas VJ, Rodrigues AP. Frailty syndrome related to disability in the elderly. Acta Paul Enferm. 2012; 25(4):589-94. doi: http://dx.doi.org/10.1590/ S0103-21002012005000016 
13. Moreira PL, Correa CR, Corrente JE, Martin LC, Boas PJFV, Ferreira ALA. Anthropometric, functional capacity and oxidative stress changes in Brazilian community-living elderly subjects. A longitudinal study. Arch Gerontol Geriatr. 2016; 66(1):140-6. doi: http://dx.doi.org/10.1016/j. archger.2016.05.013

14. Geib LTC. Social determinants of health in the elderly. Cienc Saúde Coletiva. 2012; 17(1):12333. doi: http://dx.doi.org/10.1590/S141381232012000100015

15. Andrade CY. Acesso ao ensino superior no Brasil: equidade e desigualdade social. Rev Ensino Superior Unicamp [Internet]. 2012 [citado 2017 jun. 19]; 6(7):18-26. Disponível em: https://www. revistaensinosuperior.gr.unicamp.br/edicoes/ ed06_julho2012/Cibele_Yahn.pdf

16. Instituto Brasileiro de Geografia e Estatística. Grandes Regiões e Unidades da Federação: esperança de vida ao nascer segundo projeção populacional: 1980,1991-2030 [Internet]. 2016 [citado 2017 jun. 19]. Disponível em: http:// www.ibge.gov.br/home/presidencia/noticias/ imprensa/ppts/0000000243.pdf.
17. Instituto Brasileiro de Geografia e Estatística. Projeções da população: Brasil e Unidades da Federação [Internet]. 2013 [citado 2017 jun. 19]. Disponível em: http://www.ibge.gov.br/apps/ populacao/projecao/

18. Fausto MCR, Giovanella L, Mendonça MHM, Seidl H, Gagno J. The position of the Family Health Strategy in the health care system under the perspective of the PMAQ-AB participating teams and users. Saúde Debate. 2014; 38(esp):13-33. doi: http:// dx.doi.org/10.5935/0103-1104.2014S003

19. Malta DC, Santos MAS, Stopa SR, Vieira JEB, Melo EA, Reis AAC. Family Health Strategy Coverage in Brazil, according to the National Health Survey, 2013. Cienc Saúde Coletiva. 2016; 21(2):32738. doi: http://dx.doi.org/10.1590/141381232015212.23602015 